DOI https://doi.org/10.18551/rjoas.2017-03.18

\title{
SATISFACTION, TRUST AND ATTACHMENT ON BRAND COMMUNITY CONTEXT: LOYALTY IMPACT
}

\author{
Rahmatiyah Ridha ${ }^{1,2 *}$, Yulianto Edi ${ }^{2}$, Kusumawati Andriani ${ }^{2}$ \\ ${ }^{1}$ Business Administration Program, IISIP Yapis Biak, Papua Province, Indonesia \\ ${ }^{2}$ Department of Business Administration, Faculty of Administrative Science, \\ University of Brawijaya, Indonesia \\ *E-mail: ridharahmatiah@gmail.com
}

\begin{abstract}
Consumer behavior is dynamic, means the behavior of a consumer, a group or a community able to change and moving all the time. Therefore, related the satisfaction, trust, attachment, and loyalty on a brand able to form the perception of the brand. The purpose of the current study is to examine and to explain the relationship between the four variables, such as brand satisfaction, brand trust, brand attachment, and brand loyalty. The object used in the current study is the member of Yamaha motorcycle community which is divided into three community. They are ; Majesty (Malang Jupiter Series Community) community, MFCM (Mio Fans Club Malang) community, and YVCI (Yamaha Vixion Club Indonesia) community. The proportional simple random method was used with 108 respondent involved and then Generalized Structural Component Analysis (GeSCA) used to analyze the data. The result show that the relationship between brand satisfaction and brand satisfaction is significant, the relationship between brand satisfaction and brand attachment is significant as well, the significant relationship has resulted between brand attachment and brand loyalty, also the significant relationship between brand trust and brand loyalty is obtained.
\end{abstract}

\section{KEY WORDS}

Brand satisfaction, brand trust, brand attachment, brand loyalty.

Consumer satisfaction on the brand become one of the crucial aspects when the company involves in the competitive market. Brand satisfaction defined by Engle (1990) as the result of consumer's subjective evaluation toward a brand has selected or exceed what the consumer expect. The consumer trust on a brand able to achieved if the marketer able to create and maintain the positive emotional relationship with the consumers. The brand trust is the general consumer desire which beliefs on a brand able to fulfill their need and have the ability as same as the function is (Chaudhuri and Holbrook, 2001). The consumer attachment to a brand was created when the consumer getting the good benefit from a brand. The brand attachment defined by Lacoeuilhe in Louis and Lombart (2010) as the psychology variable which shows up the effective relationship with a brand that imperishable and unchanged (the separation is painful) and shows the closeness relationship with a brand psychologically. Furthermore, the brand loyalty on a brand become the important thing to marketer since loyalty is the business heart and without the loyalty, a company might unable to survive in the business competitive. The brand loyalty is the commitment that strongly held to re-buy a product or service which more preferable continually in the future, so that the consumer do the re-purchasing in the same brand, even though marketing efforts influence the situation and potentially cause switching behavior (Oliver, 1999).

Satisfaction, trust, attachment and loyalty is the involvement attitude in a consumer self when they use a brand and it has an impact on a brand continuity. The rigorous competitiveness in motorcycle product category will reduce the consumer loyalty in the branding competition. The reduction of the consumer loyalty due to switching the consumer behavior become a threat for the company since the brand loyalty is the key to many companies to manage the long-term relationship with the consumer. Generally, the consumer loyalty will be held the consumer commitment even though get any offering from the competitor and un-loyalty consumer will be easy to switch to the cheaper price factor. 
Yamaha brand motorcycle brand is the favorite one among the wide society though had competed in the automotive market in Indonesia. The producer of Yamaha motorcycle in Indonesia has released several types of the motorcycle which ready to compete with the other brand such as Honda, Kawasaki, Suzuki, etc. The product of Yamaha motorcycle in Indonesia also diverse enough and able to attract the potential consumer and their customer. In the current study, involving three communities to testing the satisfaction, trust, attachment and loyalty toward a brand.

The three community among MFCM (Mio Fans Club Malang), YVCI-N (Yamaha V-ixion Club Indonesia) Malang city Chapter and Majesty (Malang Jupiter Series Community). Those communities formed based on the similarity of the members who use the motorcycle such as Yamaha Mio, V-ixion and Jupiter along with their love for its brand. The brand community, as the set of structural by the social relationship the brand users (Hasan: 2014). In the marketing context, the role of the community become a crucial thing to the producer, indeed the producer sees it as a strategy. The existences of the various community which take a brand name of a company be a good thing to producer side. The various communities existences as the trigger the sales of a product that carried and the brand community able to build up the brand image in the wider society. The study related the community become an interesting thing, moreover if related with the variable of brand satisfaction, brand trust, brand attachment and brand loyalty. For further, the study applied in Malang city which have many potentials in a form a certain community if it is related a brand. Community a product brand really attractive to study deeper and the rapid growth of the community of Yamaha motorcycle attractive to tested further.

\section{THEORETICAL REVIEW}

Brand Satisfaction. The definition of brand satisfaction is the satisfaction of consumer toward a brand that they used. While using and after consuming a product or service, the customer develops satisfaction and un-satisfaction feeling. Tjiptono (1997: 35), the technique to measure the consumer satisfaction directly, able to use a question or statement about how far the expectation toward a product has achieved. According to Mowen and Minor (2001), define the consumer satisfaction as the entire attitude which is showed by the consumer on product or service after they get and use it. Chinomona (2013) found that between brand satisfaction with brand attachment is positively related. According to Belaid and Behi (2011), the relationship between satisfaction and attachment yet explicitly evoke in the literature. The affective dimension of satisfaction showed a possibility relation with the brand attachment.

Sahin et al., (2013) testing the relationship of brand satisfaction and brand trust in the phone market. The result shows that the brand satisfaction has positive relations with the brand trust although explore on product category only. Asadollahi et al., (2012) develops a comprehensive model that combine the satisfaction, trust, and attachment. Further the finding show that the brand satisfaction influences the brand trust directly. Drennan et al., (2015) elaborated and testing the satisfaction with the loyalty of a wine brand through a study on the consumer in the cross-countries. Based on these test, obtain the brand satisfaction has a positive impact toward the brand loyalty on the wine product in a whole different country. The study of Marist et al., (2014) found that brand loyalty formed by the brand satisfaction.

$\mathrm{H} 1$ : Brand satisfaction positively and significantly has impact toward brand attachment;

$\mathrm{H} 2$ : Brand satisfaction positively and significantly has impact toward brand trust;

H3: Brand satisfaction positively and significantly has impact toward brand loyalty.

Brand trust. The consumer trust on a brand obtained if the market able to create and held the relationship between emotional with the consumer only. The positive emotional relationship has to build for the un-short time but has to do consistently and persistently (Ferrinadewi, 2008). According to Ferrinadewi (2008), the trust sourced by the consumer expectation will be fulfilled by the brand commitment.

When their expectation is unfulfilled so the trust might be diminished or even will be gone. When the consumer trust is gone then will be difficult for a company to grow it back. 
According to Delgado (2004) in Ferrinadewi (2008), the brand trust is the expectation to the reliability and the good intensity of brand. Brand trust reflects the two important components that are brand reliability and brand intentions. Based on Tsiotsou (2010) brand trust has the positive relation with the brand attachment. Esch et al., (2006) stated that brand trust as the result of change and communal relations and brand attachment determination as for the reflection of the relationship of a brand over time.

$\mathrm{H} 4$ : Brand trust positively and significantly has impact toward brand attachment.

Brand attachment. The emotional attachment with a brand as the emotional bond which is same between a person and a brand is marked with the feeling deep connected, love and enthusiasm (Thomson et al., 2005; Cheong, 2013). Park et al., (2010) define the brand attachment as a power bound which connecting a brand with a person. This bond is showed by the memory network that rich and accessible (mental description) which involved of mind and feeling about a brand and the relation of a brand with the self. Brand attachment more accurate than predict an intention to do the behavior which uses consumer resources significantly (time, money, and reputation). This matter as the strong predictor of the consumer behavior which actually came out by the brand power attitude as well. Pedeliento et al., (2014) expressed the role of the brand attachment as the driver of brand loyalty and also brand attachment positive related with brand loyalty (Tsiotsou, 2010).

$\mathrm{H} 5$ : Brand attachment positively and significantly has impact toward brand loyalty.

Brand loyalty. Mowen and Minor (2001) determine a loyalty attitude measurement using purchase behavior and brand commitment. Brand loyalty is the standardization the closeness customer on a brand, and positive feeling toward a brand (Ismail, 2013). Furthermore, Ismail (2013) define brand loyalty as how far a customer as show the positive attitude toward a brand, has a commitment to a certain brand, and willing to do repurchase in the future over the time. The higher of trust feeling on a brand the higher customer loyalty on a brand (Belaid dan Behi, 2011). The study of So et al., (2013), state that brand trust has positive relations with the brand loyalty as well.

H6: brand trust positively and significantly has impact toward brand loyalty.

\section{METHODS OF RESEARCH}

The current study is the explanation research type with positivist research or quantitative approach.

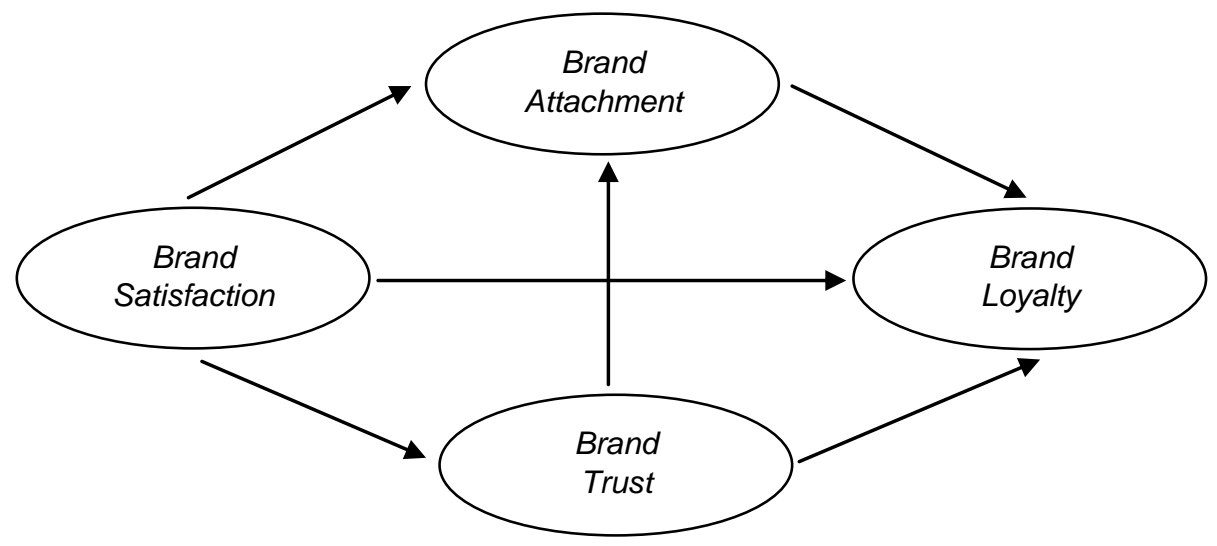

Figure 1 - Research Framework

The research location is taken in Malang city and the research object is the members of motorcycle community which use the Yamaha brand. The population in the current study is homogeny which consists of three communities of Yamaha brand with the amount of 226 members, that are: Majesty community (Malang Jupiter Series Community) as 35 people, MFCM (Mio Fans Club Malang) as 39 people and YVCI (Yamaha V-Dixon Club Indonesia) Malang city chapter as 152 person. The sampling technique in the current study is 
proportional simple random sampling method and the amount of sample determined by the slovin formula was obtained as 108 respondents. The analysis technique used is descriptive analysis and inferential statistical analysis is used to prove the hypothesis proposed in this research by using Generalized Structures Component Analysis (GeSCA).

\section{RESULTS AND DISCUSSION}

The result of the hypotheses testing with GeSCA is known that the six hypotheses showing a significant impact. To knowing what is the structural model good or not, it able to see the value of FIT, AFIT and NPAR, as followed:

Table 1 - Goodness of Fit

\begin{tabular}{|c|c|}
\hline \multicolumn{2}{|c|}{ Model Fit } \\
\hline FIT & 0,856 \\
\hline AFIT & 0,849 \\
\hline NPAR & 66 \\
\hline
\end{tabular}

Based on the table above, the model able to explain the whole variable have the value of FIT as 0,856 , the diversity of brand satisfaction, brand attachment, brand trust, and brand loyalty is explained by the model. While the homogeneities is explained by the values of AFIT as $84,9 \%$, means when viewed from the AFIT that the model made indicate suitably.

Table 2 - The Result of Testing Hypothesis

\begin{tabular}{|c|c|c|c|c|}
\hline Hypothesis & Estimate & SE & CR & Information \\
\hline $\mathrm{H} 1$ & 0,758 & 0,093 & $5,97^{*}$ & Significant \\
\hline $\mathrm{H} 2$ & 0,766 & 0,056 & $7,57^{*}$ & Significant \\
\hline $\mathrm{H} 3$ & 0,698 & 0,098 & $4,02^{*}$ & Significant \\
\hline $\mathrm{H} 4$ & 0,688 & 0,097 & $6,91^{*}$ & Significant \\
\hline $\mathrm{H} 5$ & 0,643 & 0,070 & $9,19^{*}$ & Significant \\
\hline $\mathrm{H} 6$ & 0,653 & 0,070 & $5,18^{*}$ & \\
\hline
\end{tabular}

Hypothesis 1, show that brand satisfaction toward brand attachment is significant as 0,758 . This result similar with the previous study of Chinomona (2013), Belaid dan Behi (2011), and Esch et al., (2006) which state that brand satisfaction positively and significantly has an impact toward brand attachment. In order to ensure on a brand, then needed the strategy to support the brand satisfaction. The feeling of satisfying when using the product due to the attachment on its brand. The best thing that able to given on a brand able to improve the higher attachment.

The result of hypothesis 2 shows that brand satisfaction significantly influence brand trust (.766). The result of the current study appropriate with the previous study of Marist et al., (2014), Chinomona (2013), Sahin et al., (2013) and Asadollahi et al., (2012). The satisfaction that is perceived on Yamaha brand involves on brand trust. The product performance contributes the interest of the satisfaction which leads the perceive of trust on a product.

Hypothesis 3 prove the variable of brand satisfaction influence the loyalty significantly as 0,698 . The result of the current study appropriate with the previous study of Drennan et al., (2015) and Marist et al., (2014). Drennan et al., (2015) found that the brand satisfaction has a positive impact toward brand loyalty of wine in the whole different country. This result indicates that the consumer who is satisfied and loyal tend to be brand advocate which give brand exposure and guarantee to the new customer through word of mouth communication. The brand satisfaction fosters the confidence to use a certain brand continuously. The perceive good satisfaction able to create the strong loyalty on a brand.

Hypotheses 4 provide significances relationship between brand trust and brand attachment as 0,688 . The result of the current study appropriate with the previous study of Chinomona (2013), Tsiotsou (2010) and Esch et al., (2006). The perceive of trust on a brand contribute to the attachment feeling. The goodness of the product able to improve the user trust moreover increase to the attachment feeling. 
Hypotheses 5 show that the brand attachment influences the brand loyalty significantly as 0,643 . The result of the current study similar with the previous study of Pedeliento et al., (2014), Belaid and Behi (2011), and Tsiotsou (2010). The attachment leads to the loyalty feeling, moreover if unable to switching to the other brand. The attachment which had long term denote the loyalty to the brand.

Hypotheses 6 prove that the brand trust has a significant impact on the brand loyalty as 0,653 . The result of the current study similar with the previous study of Drennan et al., (2015), Marist et al., (2014) So et al., (2013) Belaid and Behind, 2011), and Tsiotsou (2010). The perceive of trust leads to the perceive of loyal toward a brand. If the trust had been perceived continuously, then the loyalty on a brand will stand endlessly.

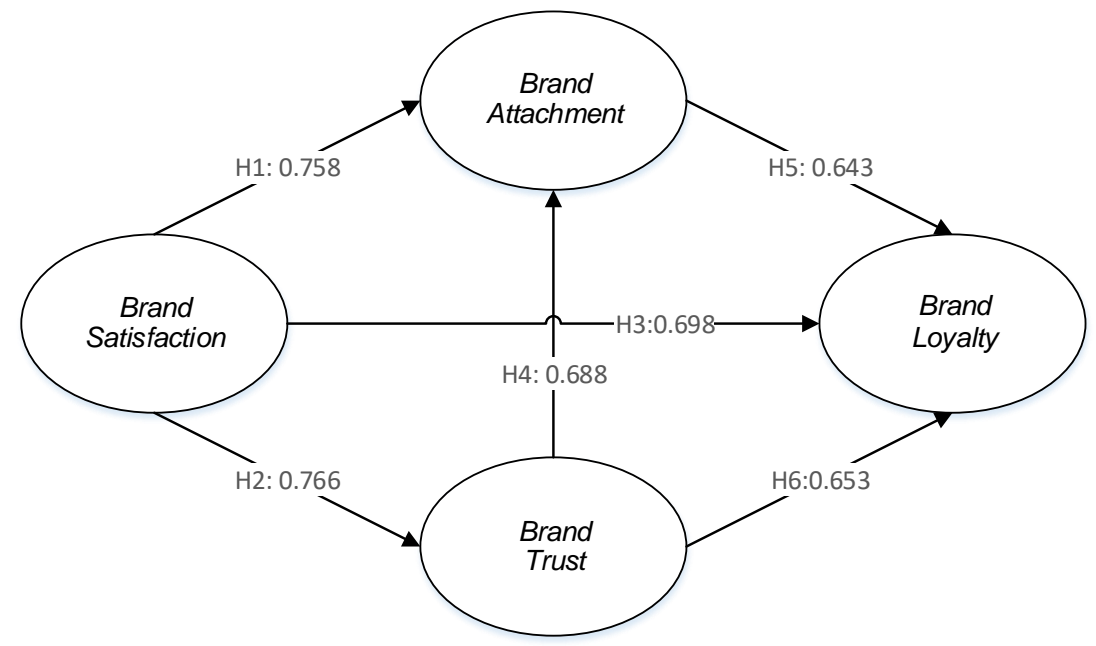

Figure 2 - The Output Model of GeSCA

Based on Figure 2, the brand satisfaction value toward brand attachment higher than brand loyalty toward brand satisfaction. Therefore, the brand attachment able to make stronger the impact of brand satisfaction toward brand loyalty. Furthermore, the value of brand satisfaction toward brand trust is higher than the value of brand satisfaction toward brand loyalty. Therefore, brand trustable to make stronger the impact of brand satisfaction on brand loyalty. Further, the value of brand satisfaction toward brand attachment higher than the value of brand satisfaction toward brand attachment through brand trust. Therefore, brand trust able to make stronger brand satisfaction on brand attachment.

\section{CONCLUSION}

This study attempt to explain the influence of satisfaction, trust, attachment be in effect on Yamaha brand community toward loyalty. The role of the loyalty in the marketing research make the researcher attracted to testing those variables due to the loyalty involve the consumer behavior into the commitment to do re-purchase in the long term. That becomes important since the implication toward the development of brand on a company.

There are several limitations in the current study, that is in this study focus on the one location only. So the further study able to do in the different location type. Besides, only use the three communities of a brand as the research object. So that, the result might be generalized into the other product of Yamaha, but still, has a possibility that the finding unable be applied on a cross-company or cross-industry. The further research able to examine more than one community with the different of the brands.

Furthermore, there are many un-involve variables in the current study. The involvement of the other variable and indicators will influence the result by the current study interpretation. Then, the amount of the involvement respondent in the current study as the 108 people only. The more of respondent involvement will be able to make the result more generalized. 


\section{REFERENCES}

1. Asadollahi, Amin, Mohammad Jani, Parisa Pourmohammadi Mojaveri, Farshad Bastani Allahabadi. 2012. Investigating the Effect of Brand Satisfaction, Brand Trust and Brand Attachment on Purchase Behavior of Customers. Research Journal of Applied Sciences, Engineering and Technology 4 (17): 3182-3187, ISSN: 2040-7467.

2. Belaid, Samy and Azza Temessek Behi. 2011. The role of attachment in building consumer-brand relationships: an empirical investigation in the utilitarian consumption context. Journal of Product \& Brand Management 20/1; 37-47.

3. Chaudhuri, Arjun and Morris B Holbrook. 2001. The Chain of Effect from Brand Trust and Brand Effect to brand preformance: The Role of Brand Loyalty. Journal of Market Focused Management.

4. Cheong, Andrew Lee Hock. 2013. An Exploration of Antecedents and Consequences of Brand Attachment among a Cross Section of Malaysian Consumers. Asian Social Science; Vol. 9, No. 5.

5. Chinomona, Richard. 2013. The Influence of Brand Experience On Brand Satisfaction, Trust And Attachment In South Africa. International Business \& Economics Research Journal. Volume 12, Number 10.

6. Drennan, Judy, Constanza Bianchi, Silvia Cacho-Elizondo, Sandra Louriero, Nathalie Guibert, William Proud. 2015. Examining the role of wine brand love on brand loyalty: A multi-country comparison. International Journal of Hospitality Management 49; 47-55.

7. Engel, J. F., D. B. 1990. Customer Behavior. $5^{\text {th }}$. Ed. Upper Saddle River. NJ: Prentice Hall. Inc.

8. Esch, Franz-Rudolf, Tobias Langner, Bernd H. Schmitt, Patrick Geus. 2006. Are brands forever? How brand knowledge and relationships affect current and future purchases. Journal of Product \& Brand Management; 15/2 (2006) 98-105.

9. Ferrinadewi, Erna. 2008. Merek \& Psikologi Konsumen. Yogyakarta: Graha IImu.

10. Hasan, Ali. 2014. Marketing dan Kasus-kasus Pilihan. Jakarta: CAPS (Center for Academic Publishing Service).

11. Ismail, Muhammad. 2013. Strategi Pemasaran untuk Membangun Citra dan Loyalitas Merek. Bogor: PT. Penerbit IPB Press.

12. Louis, Didier, Cindy Lombart. 2010. Impact of brand personality on three major relational consequences (trust, attachment, and commitment to the brand). Journal of Product \& Brand Management; 19/2, 114-130.

13. Marist, Adi Irianto, Lilik Noor Yuliati, Mukhamad Najib. 2014. The Role of Event in Building Brand Satisfaction, Trust and Loyalty of Isotonic Drink. International Journal of Marketing Studies; Vol. 6, No. 6.

14. Mowen, John. C dan Michael Minor. 2001. Perilaku Konsumen. Bandung: PT. Penerbit Erlangga.

15. Oliver, R.L. 1999. Whence Consumer Loyalty?. Journal of Marketing; Vol. 63 No. 4, pp. 33-44.

16. Park, C. et al 2010. Brand Attachment and Brand Attitude Strength: Conceptual and Empirical Differentiation of Two Critical Brand Equity Drivers. Journal of Marketing Vol. 74 (ISSN: 0022-2429), 1-17.

17. Pedeliento, G. et al 2015. Brand and product attachment in an industrial context: The effects on brand loyalty. Industrial Marketing Management.

18. Sahin, Azize, Hakan Kitapci, Cemal Zehir. 2013. Creating Commitment, Trust and Satisfaction for a Brand: What is the Role of Switching Costs in Mobile Phone Market?. Social and Behavioral Sciences 99 (2013) 496-502.

19. So, Kevin Kam Fung, Ceridwyn King, Beverley A. Sparks, Ying Wang. 2013. The influence of customer brand identification on hotel brand evaluation and loyalty development. International Journal of Hospitality Management 34; 31-41.

20. Tjiptono, Fandy. 1997. Total Quality Service. Yogyakarta: Gramedia.

21. Tsiotsou, Rodoula. 2010. Brand Loyalty through Brand Attachment and Brand Trust: A Relational Perspective. 